\title{
OPEM
}

www.opem.org

Oriental Pharmacy and Experimental Medicine 2010 10(3), 141-149

DOI 10.3742/OPEM.2010.10.3.141

\section{Comparison of heavy metal concentrations in hairs of a small sample of Korean patients taking traditional herbal medicine}

\author{
Yeong-chul Park ${ }^{1}$, Myung-dong Kim², Sung kyun Park ${ }^{3}$, Hyundo Kim ${ }^{4}$, and Sundong Lee ${ }^{5 *}$ \\ ${ }^{1}$ GLP Center, Catholic University of Daegu, Hayang, Keongsan, Keongbuk, 712-702, Korea; ${ }^{2}$ Dept. of Physiology, \\ School of Oriental Medicine, Sangji University, Woosan-dong, Wonju-si, Kangwon-do, 220-702, Korea; ${ }^{3}$ Dept. of \\ Environmental Health Sciences, School of public Health, University of Michigan. Ann Arbor. MI. 48109. USA; \\ ${ }^{4}$ Acupuncture and Oriental Medicine program, National University of Health Sciences, Lombard, IL 60148, USA; \\ ${ }^{5}$ Dept. of Preventive medicine, School of Oriental Medicine, Sangji University, Woosan-dong, Wonju-si, Kangwon-do, 220- \\ 702, Korea
}

Received for publication March 16, 2010; accepted September 7, 2010

\begin{abstract}
SUMMARY
A concern of safety issue for traditional herbal medicine is the possibility of some herbs containing heavy metals responsible for several cases of metal poisoning. In our previous study, the physiological levels of heavy metals, such as $\mathrm{Cd}, \mathrm{Cu}, \mathrm{Hg}$ and $\mathrm{Pb}$, were examined to evaluate a potential risk in patients taking herbal medicine. In this study, the levels of 12 heavy metals, including non-metallic element, Se, were analyzed in hair and compared to the results from the previous study. In the previous study, the levels of $\mathrm{Cd}, \mathrm{Cu}, \mathrm{Hg}$ and $\mathrm{Pb}$ in hair showed a significantly lower odds ratio than 1 . In this study, however, all metals did not show any significant odds ratio higher or lower than 1 even if 5 of 12 metals showed lower odds ratio than 1 . In addition, the levels of metal concentrations, especially for $\mathrm{Cu}, \mathrm{Fe}, \mathrm{Pb}$ and $\mathrm{Zn}$, exceeding the $\mathrm{WHO}$ reference values were observed in hair. However, any evidence for metal accumulation in hair caused by taking herbal medicines for long duration was not observed in analysis of multiple regression and odds ratio from case-control study. This result would show another possibility for a role of herbs as a non-enzymatic chelator inhibiting the gastrointestinal absorption of heavy metals.
\end{abstract}

Key words: Herbal medicine; Hair metals concentration; Chelator, Odds ratios

\section{INTRODUCTION}

One of the main benefits of herbal medicine treatment is its apparent lack of side effects compared with the drug therapies used in allopathic medicine. For this reason, herbal medicine has been used as a

${ }^{*}$ Correspondence: Sundong Lee, Dept. of Preventive medicine, School of Oriental Medicine, Sangji University, Woosan-dong, Wonju-si, Kangwon-do, 220-702, Korea. Tel: +82-33-730-0665; Fax: +82-33-738-7825; E-mail: sdlee @sangji.ac.kr main traditional therapy and is becoming increasingly popular as one of the tools for alternative or complementary therapies in western countries (Ernst and Coon, 2001; Ernst, 2005). However, evidences from various countries suggest that toxic heavy metals in Asian herbal medicine may constitute a serious health problem. One of safety issues is the possibility of some herbs containing heavy metals (Caldas and Machado, 2004), as herbal medicine was found to be responsible for several cases of metal poisoning. 
In our previous study (Park et al., 2006), the physiological levels of heavy metals such as $\mathrm{Cd}$, $\mathrm{Cu}, \mathrm{Hg}$ and $\mathrm{Pb}$ were studied to evaluate a potential risk in patients taking herbal medicine. The levels of metals that exceeding the $\mathrm{WHO}$ reference values (WHO, 1996) were observed in hair samples. In addition, some of metals showed the possibility of accumulation in the body and high odds ratio after adjusting confounding factors. However, some of metals in samples from the people taking herbal medicine showed decreased level and odds ratio compared to those of the control group. This may explain the possible role of herbal medicine as a chelator for heavy metals in the body. There are number of natural (non-synthetic) chelators such as herbs, amino acids, and other nutritional supplements (Georgiou, 2005). One of many herbal components, flavonoid and derivatives, dislodge heavy metal molecules from the cell receptors and capture them so that they may be excreted from the body (Lim et al., 2001; Pierre et al., 2003).

However, evidences from various countries have still suggested that toxic heavy metals in herbal medicine constitute a serious health problem (Hasegawa et al., 1997; Cheng et al., 1998; Ernst, 2000). On the contrary, there has been no report for health problems related to heavy metals in herbal medicine in Korea. One of the possible reasons for lack of incidence in Korea compared to other countries seems to be due to a difference in methods of taking herbal medicine. In Korea, a popular method of intake is decoction that is extracted by boiling herbs, thus contaminated metals could be removed. On the contrary, products manufactured from raw herbal materials have been sold in western countries.

However, the conclusion that herbal medicine may act as a chelator for heavy metals in the body could not be applied to all kinds of heavy metals since only four kinds of heavy metals were evaluated in our previous study (Park et al., 2006). This means that there may be metal poisoning caused by other heavy metals contaminated in herbal medicine.
There are 35 metals that concern us because of food and medicine-mediated occupational exposures. In this study, 12 kinds of metals including 11 heavy metals and 1 non-metallic trace element, Se, were analyzed in hair samples from the people who were treated with herbal and non-herbal medicine as a tool for medical therapy. In addition, the risk level for each metal concentration by taking herbal medicine was evaluated as an odds ratio.

\section{MATERIALS AND METHODS}

\section{Study population}

Hair samples were analyzed from one Oriental medical clinic located in Seoul. Patients were simply classified into two groups as herbal and non-herbal medicine based on therapy tools. The herbal group had taken herbal medicine-type like decoction and pill for duration ranging from 1 to 124 months. A "decoction" is defined as herbal medicine boiled in water to yield herbal extract. A "pill" is a mixture of raw herbs without boiling. The non-herbal medicine group as control group consisted of patients neither taking decoction nor pill. Patients were asked to fill out a questionnaire relating with job history, residence, alcohol intake, smoking, and etc. A comparison of general characteristics between the subjects with herbal and non-herbal is summarized in Table 1.

\section{Hair sample collection}

With regards to hair, the removal of exogenous contamination is mandatory prior to analysis. Samples were repeatedly washed under stirring with a mixture of ethyl ether and acetone $(3+1, \mathrm{v} / \mathrm{v})$ (Merck and Germany). After drying, 5\% EDTA solution (Merck and Germany) was added and stirred for 1 hour. Samples were then added with $2 \mathrm{ml}$ of $\mathrm{HNO}_{3}$ and digested overnight. $1 \mathrm{ml}$ of $\mathrm{H}_{2} \mathrm{O}_{2}$ was then added. The MW digestion settings were as follows: (i) $3 \mathrm{~min}$ at $250 \mathrm{~W}$ followed by 6 min at $0 \mathrm{~W}$; (ii) $5 \mathrm{~min}$ at $250 \mathrm{~W}$ and $5 \mathrm{~min}$ at $0 \mathrm{~W}$; (iii) $5 \mathrm{~min}$ at $450 \mathrm{~W}$; and (iv) 5 min at $500 \mathrm{~W}$. The digestion solutions 
Table 1. General characteristics of Non-herbal and Herbal groups

\begin{tabular}{|c|c|c|c|c|c|}
\hline & \multicolumn{2}{|c|}{ Non-herbal } & \multicolumn{2}{|c|}{ Herbal } & \multirow{2}{*}{$P$-value } \\
\hline & No & $\%$ & No & $\%$ & \\
\hline Age (years) & 133 & 28.89(13.95) & 197 & $31.25(14.72)$ & 0.145 \\
\hline sex & & & & & 0.315 \\
\hline male & 75 & 56.40 & 100 & 50.80 & \\
\hline \multirow[t]{2}{*}{ female } & 58 & 43.60 & 97 & 49.20 & \\
\hline & 133 & 100.00 & 197 & 100.00 & \\
\hline Marriage & & & & & 0.177 \\
\hline Yes & 59 & 44.70 & 103 & 52.30 & \\
\hline \multirow[t]{2}{*}{ No } & 73 & 55.30 & 94 & 47.70 & \\
\hline & 132 & 100.00 & 197 & 100.00 & \\
\hline Food preference & & & & & 0.018 \\
\hline Meat & 13 & 9.80 & 5 & 2.60 & \\
\hline Vegetable & 9 & 6.80 & 23 & 11.70 & \\
\hline Mixed & 14 & 10.50 & 26 & 13.30 & \\
\hline \multirow[t]{2}{*}{ Others } & 97 & 72.90 & 142 & 72.40 & \\
\hline & 133 & 100.00 & 196 & 100.00 & \\
\hline Alcohol & & & & & 0.579 \\
\hline Yes & 79 & 59.40 & 123 & 62.40 & \\
\hline \multirow[t]{2}{*}{ No } & 54 & 40.60 & 74 & 37.60 & \\
\hline & 133 & 100.00 & 197 & 100.00 & \\
\hline Smoke & & & & & 0.498 \\
\hline Yes & 99 & 74.40 & 153 & 77.70 & \\
\hline \multirow[t]{2}{*}{ No } & 34 & 25.60 & 44 & 22.30 & \\
\hline & 133 & 100.00 & 197 & 100.00 & \\
\hline Residential Area & & & & & 0.561 \\
\hline Big city & 61 & 47.70 & 100 & 50.80 & \\
\hline Rural & 43 & 33.60 & 68 & 34.50 & \\
\hline Industrial City & 9 & 7.00 & 15 & 7.60 & \\
\hline \multirow[t]{2}{*}{ Etc } & 15 & 11.70 & 14 & 7.10 & \\
\hline & 128 & 100.00 & 197 & 100.00 & \\
\hline Job & & & & & 0.895 \\
\hline White collar & 18 & 13.50 & 30 & 15.20 & \\
\hline Blue collar & 44 & 33.10 & 62 & 31.50 & \\
\hline \multirow[t]{2}{*}{ Unemployed } & 71 & 53.40 & 105 & 53.30 & \\
\hline & 133 & 100.00 & 197 & 100.00 & \\
\hline Body mass index & 95 & $22.01(3.40)$ & 162 & $21.83(3.10)$ & 0.670 \\
\hline
\end{tabular}

were diluted up to $20 \mathrm{ml}$ and stored at $2{ }^{\circ} \mathrm{C}$.

\section{Sample pre-treatment and metal analysis}

The samples were freeze-dried and then ground, homogenized and sieved $(\leq 175 \mu \mathrm{m})$ before analyses. Samples with excessive concentrations of metals were diluted with spectral-grade graphite. Sample pre-treatment and analytical methods followed US EPA procedures, Goulle's and Mortada's study (US EPA, 1981; Mortada et al., 2002; Goulle et al., 2005). Also, the whole analytical procedure, from sampling to final analytical determinations, was 
carried out according to a pre-established quality assurance protocol (Cubadda et al., 2003). Briefly, this included the use of powder-free glove sand non-contaminating equipment for sample collection and handling, sample storage in brand-new jars of high-density polyethylene previously submitted to a decontaminating acid treatment, sample transport in plastic envelopes in order to protect the jars from dust and aerial contamination, and sample treatment carried out by trained personnel under clean room conditions. Once in the laboratory, samples were stored at room temperature in the dark until analysis in less than 15 days.

\section{$\mathrm{AS}, \mathrm{Cd}, \mathrm{Co}, \mathrm{Cr}, \mathrm{Cu}, \mathrm{Fe}, \mathrm{Mn}, \mathrm{Ni}, \mathrm{Pb}$, Se and $\mathrm{Zn}$}

Samples were treated using $65 \mathrm{ml}$ of cleaning solution (186 ml of ethyl alcohol, $93 \mathrm{ml}$ of acetone and $371 \mathrm{ml}$ of $\mathrm{n}$-hexane to $1 \mathrm{~L}$ volumetric flask) for $12 \mathrm{~h}$. Each aliquot $(0.1-0.2 \mathrm{~g})$ from well homogenized samples was moved to a digestion vessel. The aliquots were mixed with $10 \mathrm{ml}$ of $1: 1 \mathrm{HNO}_{3}$, and then covered with a watch glass. Treated samples were heated to $95 \pm 5$ and refluxed for 10 to $15 \mathrm{~min}$ without boiling. After adding $5 \mathrm{ml}$ of concentrated $\mathrm{HNO}_{3}$, the samples were allowed to cool and were refluxed for 30 minutes. This step was repeated until no brown fume was given off by the sample, showing the complete reaction with $\mathrm{HNO}_{3}$. Using a ribbed watch glass, the solution was evaporated to approximately $5 \mathrm{ml}$ at $95 \pm 5$ for two hours. The samples were cooled again and $3 \mathrm{ml}$ of $30 \% \mathrm{H}_{2} \mathrm{O}_{2}$ was added. In order for the peroxide reaction the vessels were covered with a watch glass and placed on the heat source for warming until effervescence subsided. Then peroxide solution was added in 1 $\mathrm{ml}$ aliquots. The aliquots were warmed until the effervescence was minimal. The aliquots were covered with a ribbed watch glass. The acid-peroxide digest of the aliquot was heated until the volume was reduced to approximately $5 \mathrm{ml}$. The solution was covered over the bottom of the vessel at all times. After cooling, it was diluted to $50 \mathrm{ml}$ with water. The particulates in digest were then removed by filtration. The filtered samples were analyzed by ICP-MS (Goulle et al., 2005). The ICP-MS analysis for 11 elements was carried out using ICP-MS spectrometer Varian Ultramass 700 (USA, 1998) with cross flow nebulizer.

\section{$\mathrm{Hg}$}

Samples were treated by using $65 \mathrm{ml}$ of cleaning solution (186 ml of ethyl alcohol, $93 \mathrm{ml}$ of acetone and $371 \mathrm{ml}$ of $\mathrm{n}$-hexane to $1 \mathrm{~L}$ volumetric flask) for $12 \mathrm{~h}$. Each aliquot $(0.1-0.2 \mathrm{~g})$ from well-homogenized samples was placed in the bottom of a BOD bottle. The aliquots $(0,1,3,5 \mathrm{ml})$ of mercury working standard containing $0-5 \mathrm{ug} / \mathrm{L}$ of mercury were transfer to a series of BOD bottles. The reagent water $(5 \mathrm{ml})$ and concentrated sulfuric acid $(5 \mathrm{ml})$ were added to the aliquots of standard and sample. Also $2.5 \mathrm{ml}$ of concentrated Nitric acid was added to them and then they were heated for two minutes at $95 \pm 3{ }^{\circ} \mathrm{C}$. After cooling, samples and standard were added by $15 \mathrm{ml}$ of $5 \%$ potassium permanganate solution and mixed. They were heated for 30 minutes at $95 \pm 3{ }^{\circ} \mathrm{C}$. After cooling, they were mixed with sodium chloride-hydroxylamine hydrochloride to reduce the excess permanganate. The standard and sample were diluted to $100 \mathrm{ml}$ with de-ionized water. The particulates in digest were removed by filtration. The filtered samples and standards were analyzed by mercury analyzer (USA, Cetac, M6000A).

\section{Reagents}

All reagents were of analytical reagent grade. High purity de-ionized water (Milli-Q system and Millipore, USA) was used throughout. Analytical reagent nitric acid (Merck, 70\%) was used after additional purification by sub-boiling distillation in quartz steel. Plastic bottles and glassware were cleaned by soaking in $20 \%(\mathrm{v} / \mathrm{v}) \mathrm{HNO}_{3}$ for $24 \mathrm{~h}$. This material was then rinsed three times with de-ionized water.

\section{Statistics}

Statistical analyses were performed separately by 
two groups. We calculated geometric means for $\mathrm{AS}, \mathrm{Cd}, \mathrm{Co}, \mathrm{Cr}, \mathrm{Cu}, \mathrm{Fe}, \mathrm{Hg} \mathrm{Mn}, \mathrm{Ni}, \mathrm{Pb}$, Se and $\mathrm{Zn}$ in hair samples of the test subjects. We performed $\mathrm{t}-$ test to compare the geometric means between the herbal groups and the non-herbal group. We also calculated percents exceeding the upper limit of the reference value ranges for each metal. We adjusted for potential confounders such as age, sex, smoking, drinking, job, and residence in the analysis. Multiple regression values ( $\beta$ (SE)) for duration taking herbal medicine were calculated after adjusting for potential confounders. ( (SE)) are the natural logarithm of each metal level plus one, for example, $\log (\mathrm{As}+1)$. Odds ratios of two groups were compared after adjusting for potential confounders. For statistical analysis, Stata (2001) statistical package (Stata 7, 2001) was used for mean \pm standard deviation (SD), geometric mean, ' $t$ ' test, multiple regression, and odds ratios.

\section{RESULTS}

Table 2 shows geometric mean and standard deviation (SD) of heavy metal concentrations in hair from all samples. Also, the WHO reference values (trace elements in Human Nutrition and
Health) for heavy metals analyzed are listed and compared to those of samples. There were $0.04 \pm$ $0.23,0.06 \pm 0.19,0.02 \pm 0.04,1.11 \pm 0.84,17.08 \pm 28.58$, $24.81 \pm 78.80,1.08 \pm 1.43,1.31 \pm 2.57,0.95 \pm 1.67,3.36$ $\pm 15.00,0.59 \pm 2.75$ and $81.10 \pm 62.52 \mu \mathrm{g} / \mathrm{g}$ hair for $\mathrm{AS}, \mathrm{Cd}, \mathrm{Co}, \mathrm{Cr}, \mathrm{Cu}, \mathrm{Fe}, \mathrm{Hg}, \mathrm{Mn}, \mathrm{Ni}, \mathrm{Pb}$, Se and $\mathrm{Zn}$, respectively. Compared to the range of $\mathrm{WHO}$ reference value for each metal, there was no sample for As, Cd, Co, Cr, $\mathrm{Hg}, \mathrm{Mn}, \mathrm{Ni}$ and $\mathrm{Se}$ exceeding the upper limit. However, $15.6 \%, 6.3 \%$, $1.8 \%$ and $3.0 \%$ of total samples for $\mathrm{Cu}, \mathrm{Fe}, \mathrm{Pb}$ and $\mathrm{Zn}$, respectively, exceeded the upper limit for $\mathrm{WHO}$ reference value.

Table 3 shows geometric means and SD of metal concentrations after adjusting potentially confounding factors such as age, sex, smoking, drinking, job, and residence. The p-value range for all metal concentrations at the level of $P=0.05$ between non-herbal group and herbal group was from $0.14-0.87$, showing no significant difference.

Table 4 presents regression coefficients and standard error (SE) for duration of herbal intake from multiple regressions of metals in hair samples. The regression coefficients indicate the levels of metals increased or decreased in hair after taking herbal medicine for one year, compared to those of

Table 2. Arithmetic mean (AM) and SD of metals in hair samples

\begin{tabular}{cccccccc}
\hline $\begin{array}{c}\text { Variables } \\
(\mu \mathrm{g} / \mathrm{kg})\end{array}$ & $\mathrm{N}$ & $\begin{array}{c}\text { Minimum } \\
\text { value }\end{array}$ & $\begin{array}{c}\text { Maximum } \\
\text { value }\end{array}$ & $\mathrm{AM}$ & $\mathrm{SD}$ & $\begin{array}{c}\text { \% exceeding WHO reference value } \\
\text { reference values }\end{array}$ & $\begin{array}{c}\text { (WHO) } \\
\text { (WH }\end{array}$ \\
\hline $\mathrm{As}$ & 330 & $\mathrm{~N} . \mathrm{D}$ & 2.44 & 0.04 & 0.23 & 0 & $100-300$ \\
$\mathrm{Cd}$ & 330 & $\mathrm{~N} . \mathrm{D}$ & 2.13 & 0.06 & 0.19 & 0 & $2-10$ \\
$\mathrm{Co}$ & 330 & $\mathrm{~N} . \mathrm{D}$ & 0.37 & 0.02 & 0.04 & 0 & $50-300$ \\
$\mathrm{Cr}$ & 330 & $\mathrm{~N} . \mathrm{D}$ & 6.35 & 1.11 & 0.84 & 0 & $300-1200$ \\
$\mathrm{Cu}$ & 330 & 1.13 & 329.58 & 17.08 & 28.58 & 15.6 & $15-25$ \\
$\mathrm{Fe}$ & 330 & N.D & 1051.82 & 24.81 & 78.80 & 6.3 & $30-60$ \\
$\mathrm{Hg}$ & 330 & N.D & 23.37 & 1.08 & 1.43 & 0 & $500-2000$ \\
$\mathrm{Mn}$ & 330 & N.D & 26.70 & 1.31 & 2.57 & 0 & $500-1500$ \\
$\mathrm{Ni}$ & 330 & N.D & 17.77 & 0.95 & 1.67 & 0 & $20-200$ \\
$\mathrm{~Pb}$ & 330 & N.D & 231.32 & 3.36 & 15.00 & 1.8 & $2-20$ \\
$\mathrm{Se}$ & 330 & N.D & 37.54 & 0.59 & 2.75 & 0 & $500-1000$ \\
$\mathrm{Zn}$ & 330 & 4.74 & 464.07 & 81.10 & 62.52 & 3.0 & $150-250$ \\
\hline
\end{tabular}

*WHO (1996), Trace elements in Human Nutrition and Health. World Health Organization, Geneva. $258-9$. **N.D: Not Detected 
Table 3. Adjusted geometric means ${ }^{a}$ and SD of metal concentrations in hair samples between non-herbal and herbal groups

\begin{tabular}{cccc}
\hline $\begin{array}{c}\text { Variables } \\
(\mu \mathrm{g} / \mathrm{kg})\end{array}$ & $\begin{array}{c}\text { Non-herbal } \\
\text { Mean(SD) }\end{array}$ & $\begin{array}{c}\text { Herbal } \\
\text { Mean(SD) }\end{array}$ & P-value \\
\hline $\mathrm{As}$ & $0.04(0.01)$ & $0.03(0.01)$ & 0.73 \\
$\mathrm{Cd}$ & $0.06(0.01)$ & $0.05(0.01)$ & 0.62 \\
$\mathrm{Co}$ & $0.02(0.00)$ & $0.02(0.00)$ & 0.59 \\
$\mathrm{Cr}$ & $1.03(0.03)$ & $0.98(0.03)$ & 0.50 \\
$\mathrm{Cu}$ & $10.82(0.08)$ & $11.34(0.06)$ & 0.64 \\
$\mathrm{Fe}$ & $6.90(0.15)$ & $8.77(0.11)$ & 0.22 \\
$\mathrm{Hg}$ & $1.18(0.07)$ & $0.94(0.05)$ & 0.14 \\
$\mathrm{Mn}$ & $0.82(0.05)$ & $0.93(0.04)$ & 0.37 \\
$\mathrm{Ni}$ & $0.68(0.05)$ & $0.66(0.04)$ & 0.86 \\
$\mathrm{~Pb}$ & $1.35(0.06)$ & $1.47(0.05)$ & 0.50 \\
$\mathrm{Se}$ & $0.24(0.04)$ & $0.30(0.04)$ & 0.41 \\
$\mathrm{Zn}$ & $65.48(0.06)$ & $66.16(0.05)$ & 0.87 \\
\hline
\end{tabular}

${ }^{a}$ Geometric means(SD) were calculated by natural logarithm of each metal level plus one, for example, $\log ($ As +1$)$. - Adjusted for sex, age, job, smoking, alcohol, residence.

Table 4. Regression coefficients for duration of combined forms (decoction and pill) of herbal intake from multiple regression of metals in hair samples after adjusting for potential confounders

\begin{tabular}{ccc}
\hline $\begin{array}{c}\text { Dependent } \\
\text { Variables }(\mu \mathrm{g} / \mathrm{kg})^{\mathrm{b}}\end{array}$ & $\begin{array}{c}\text { Duration of use (yr) } \\
\text { Beta (SE) }\end{array}$ & $\begin{array}{c}\text { P-value } \\
\mathrm{As}\end{array}$ \\
$\mathrm{Cd}$ & $0.00(0.01)$ & 0.92 \\
$\mathrm{Co}$ & $0.00(0.01)$ & 0.99 \\
$\mathrm{Cr}$ & $0.02(0.02)$ & 0.93 \\
$\mathrm{Cu}$ & $0.07(0.05)$ & 0.32 \\
$\mathrm{Fe}$ & $0.13(0.09)$ & 0.14 \\
$\mathrm{Hg}$ & $-0.01(0.02)$ & 0.15 \\
$\mathrm{Mn}$ & $0.05(0.04)$ & 0.43 \\
$\mathrm{Ni}$ & $-0.01(0.03)$ & 0.73 \\
$\mathrm{~Pb}$ & $0.02(0.04)$ & 0.52 \\
$\mathrm{Se}$ & $-0.02(0.03)$ & 0.43 \\
$\mathrm{Zn}$ & $0.04(0.03)$ & 0.21 \\
\hline
\end{tabular}

${ }^{a}$ Beta: Regression coefficients, SE: Standard error. ${ }^{\mathrm{b}}$ Beta (SE) values were calculated by natural logarithm of each metal level plus one, for example, $\log ($ As +1$)$.

the non-herbal group. Regression coefficient for duration of herbal medicine ranged from - 0.02 to $0.13 \mathrm{mg} / \mathrm{kg}$ hair for all metals. However, all metals
Table 5. Odds ratios ${ }^{a}$ for metal concentrations adjusted for potential confounders

\begin{tabular}{ccccc}
\hline $\begin{array}{c}\text { Variables } \\
(\mu \mathrm{g} / \mathrm{kg})\end{array}$ & $\begin{array}{c}\text { Odds ratios } \\
\text { for herbal use }\end{array}$ & $95 \% \mathrm{CI}$ & $P$-value \\
\hline $\mathrm{As}$ & 0.99 & 0.96 & 1.03 & 0.78 \\
$\mathrm{Cd}$ & 1.00 & 0.96 & 1.03 & 0.84 \\
$\mathrm{Co}$ & 1.00 & 0.99 & 1.01 & 0.82 \\
$\mathrm{Cr}$ & 0.95 & 0.86 & 1.03 & 0.22 \\
$\mathrm{Cu}$ & 1.00 & 0.82 & 1.22 & 0.99 \\
$\mathrm{Fe}$ & 1.07 & 0.73 & 1.55 & 0.73 \\
$\mathrm{Hg}$ & 0.90 & 0.76 & 1.07 & 0.24 \\
$\mathrm{Mn}$ & 1.03 & 0.89 & 1.19 & 0.70 \\
$\mathrm{Ni}$ & 0.99 & 0.88 & 1.12 & 0.92 \\
$\mathrm{~Pb}$ & 1.05 & 0.89 & 1.23 & 0.58 \\
$\mathrm{Se}$ & 1.05 & 0.93 & 1.18 & 0.44 \\
$\mathrm{Zn}$ & 0.97 & 0.83 & 1.13 & 0.68 \\
\hline
\end{tabular}

${ }^{\mathrm{a}}$ Odds ratios were calculated by natural logarithm of each metal level plus one, for example, $\log (\mathrm{As}+1)$.

did not show any significance in values of regression coefficients. This indicates that all levels of 12 metals would not be increased in hair when patients take herbal medicine for one year.

Table 5 presents odds ratio and standard error from case-control study, using non-herbal groups as reference values. There were $0.99,1.00,1.00,0.95$, $1.00,1.07,0.90,1.03,0.99,1.05,1.05$ and 0.97 as an odds ratio for $\mathrm{AS}, \mathrm{Cd}, \mathrm{Co}, \mathrm{Cr}, \mathrm{Cu}, \mathrm{Fe}, \mathrm{Hg} \mathrm{Mn}, \mathrm{Ni}$, $\mathrm{Pb}$, Se and $\mathrm{Zn}$. There were 4 metals of total metals such as $\mathrm{Fe}, \mathrm{Mn}, \mathrm{Pb}$, and Se showing values higher than 1 as an odds ratio for each metal. However, all metals statistically did not show any significant odds ratio higher than 1 . This indicates that people who take herbal medicine would have no possibility of higher metal accumulation in hair than the people who do not take herbal medicine.

\section{DISCUSSIONS}

Some metals (e.g., copper [Cu], selenium [Se], and zinc $[\mathrm{Zn}])$ are nutritionally essential elements at low levels but toxic at higher levels, and others (e.g., lead $[\mathrm{Pb}]$, arsenic [As], and mercury $[\mathrm{Hg}]$ ) have no known biological functions (US EPA, 2007). In this 
study, 12 elements analyzed are: As, Cd, Co, Cr, $\mathrm{Cu}, \mathrm{Fe}, \mathrm{Hg} \mathrm{Mn}, \mathrm{Ni}, \mathrm{Pb}$ and $\mathrm{Zn}$ as heavy metals, and Se as a non-metallic element since these metals are widely distributed in the farming or rural areas. "Heavy metals" are chemical elements with a specific gravity that is at least 5 times the specific gravity of water. The specific gravity of water is 1 at $4{ }^{\circ} \mathrm{C}$. Specific gravity is a measure of density of a given amount of a solid substance when it is compared to an equal amount of water. Some well-known toxic metallic elements with a specific gravity that is 5 or more times that of water are arsenic, 5.7; cadmium, 8.65; iron, 7.9; lead, 11.34; and mercury, 13.546. There are 35 metals that concern us because of food and medicine-mediated occupational exposures; 23 of these are the heavy elements or "heavy metals": antimony (Sb), arsenic (As), bismuth (Bi), cadmium $(\mathrm{Cd})$, cerium(Ce), chromium $(\mathrm{Cr})$, cobalt (Co), copper $(\mathrm{Cu})$, gallium $(\mathrm{Ga})$, gold $(\mathrm{Au})$, iron $(\mathrm{Fe})$, lead $(\mathrm{Pb})$, manganese $(\mathrm{Mn})$, mercury $(\mathrm{Hg})$, nickel $(\mathrm{Ni})$, platinum $(\mathrm{Pt})$, silver $(\mathrm{Ag})$, tellurium $(\mathrm{Te})$, thallium $(\mathrm{Ti})$, tin $(\mathrm{Sn})$, uranium (Ur), vanadium (V), and zinc (Zn). In addition, Se, even if it is non-metal, was analyzed since selenium causes poisoning in range animals when ingested by eating some plants growing in soils in which it occurs in quantity. For the sake of convenience, Se was classified as a metal in this study.

In the previous study (Park et al., 2006), 11.69\%, $26.95 \%, 20.79 \%$ and $12.66 \%$ of the total samples showed concentrations exceeding the upper limit of $\mathrm{WHO}$ reference value for $\mathrm{Cd}, \mathrm{Cu}, \mathrm{Hg}$ and $\mathrm{Pb}$, respectively. In this study, there was no sample for $\mathrm{As}, \mathrm{Cd}, \mathrm{Co}, \mathrm{Cr}, \mathrm{Hg}, \mathrm{Mn}, \mathrm{Ni}$ and Se exceeding the upper limit. However, $15.6 \%, 6.3 \%, 1.8 \%$ and $3 \%$ of total samples for $\mathrm{Cu}, \mathrm{Fe}, \mathrm{Pb}$ and $\mathrm{Zn}$, respectively exceeded the upper limit for WHO reference value. However, the sample percentages of $\mathrm{Hg}$ and $\mathrm{Cd}$ concentration in hair exceeding the upper limit for WHO reference value is in discord with that of the previous study. This study showed no sample of $\mathrm{Hg}$ and $\mathrm{Cd}$ concentrations exceeding the upper limit of WHO reference value.
The result in the previous study that some of metals in samples from the people taking herbal medicine showed decreased level and low odds ratio compared to those of the control group. This explained the possible role of herbal medicine as a chelator for heavy metals in the body. The assumption for the role of herbal medicine as a chelator in the previous study was supported by the comparison of odds ratio from case-control study, using the samples those exceeding the upper limit of who reference values. Especially, the level of $\mathrm{Cd}, \mathrm{Cu}$, $\mathrm{Hg}$ and $\mathrm{Pb}$ in hair showed a significantly lower odds ratio than 1 .

In this study, however, all metals did not show any significant odds ratio higher or lower than 1 even if 5 of 12 metals showed lower odds ratio than 1 . Thus, there is no evidence for the role of herbal medicine as a chelator in this study different from that of the previous study. This different result could be explained by the sample classification. In this study, the analysis for metal concentrations was conducted without grouping such as decoction and pill according to herbal-intake method. In the previous study, the odds ratios for metal levels in the decoction group were lower than those in the pill group. This indicates that metals in the decoction would be better excreted from the body than those in the pill group. Thus, it is expected that the pill group demolish the roles of herbal medicines as a chelator in this study.

However, there was no discrepancy in the results of regression coefficients for herbal-intake duration from both studies. This indicates that all levels of 12 metals would not be increased in hair when patients take herbal medicine for one year. Even if all metals did not show any significant odds ratio higher or lower than 1 , no increase in hair samples from patients taking herbal medicine would explain another possibility for the role of herbal as a non-enzymatic chelator.

Several other dietary components affect the absorption of metals. These factors, along with essential trace elements such as calcium, iron, and 
vitamin $\mathrm{D}$, amino acid and flavonoids may show some evidence in decreasing the severity of heavy metal toxicity. Miller et al (Miller et al., 1990) presented an extensive review of interactions between metals and essential elements, but additional and more recent studies have been conducted. Regular meals as well as higher total food and fat intake have been associated with decreased gastrointestinal lead absorption (Rabinowitz et al., 1980; Bithoney, 1986). Experimental, epidemiologic, and clinical investigations have repeatedly shown that nutritional intervention can play an important role in the toxicity associated with heavy metals, especially in more vulnerable populations (Fong, 2002; Kabelitz, 1998). Studies show that as dietary zinc increases, lead absorption and its subsequent toxicity decrease, indicating that zinc exerts its effect on lead in the gastrointestinal tract (Lucas et al., 1996; Han et al., 1996). Thus it is suggested that one of reasons for no increase in hair samples from patients taking herbal medicine can be explained by various components including essential trace elements and nutritional materials in herbal medicine. These various components could play a role as a chelator with capacity for non-enzymatic binding to heavy metals, inhibiting the gastrointestinal absorption of heavy metals.

In summary, the levels of metal concentrations, especially for $\mathrm{Cu}, \mathrm{Fe}, \mathrm{Pb}$ and $\mathrm{Zn}$ that exceeding the WHO reference values were observed in hair. However, any evidence for metal accumulation in hair caused by herbal medicine intake for long duration was not observed in analysis of multiple regression and odds ratio from case-control study. This result would show another possibility for a role of herbal as a non-enzymatic chelator inhibiting the gastrointestinal absorption of heavy metals.

\section{ACKNOWLEDGEMENTS}

This study was sponsored by Youngdeungpo Oriental medical clinic in Seoul and by active participation from the patients. Youngdeungpo Oriental medical clinic administered variety of herbal medicines to the patients suffering from chronic skin disorders of vitiligo and psoriasis. Our deep gratitude goes to Youngdeungpo Oriental medical clinic and the patients for their participation.

\section{REFERENCES}

Bithoney WG. (1986) Elevated lead levels in children with nonorganic failure to thrive. Pediatrics 78, 891895.

Caldas ED, Machado LL. (2004) Cadmium, mercury and lead in medicinal herbs in Brazil. Food Chem. Toxicol. 42, 599-603.

Cheng TJ, Wong RH, Lin YP, Hwang YH, Horng JJ, Wang JD. (1998) Chinese herbal medicine, sibship, and blood lead in children. Occup. Environ. Med. 55, 573-576.

Cubadda F, Raggi A, Zanasi F, Carcea M. (2003) From durum wheat to pasta: effect of technological processing on the levels of arsenic, cadmium, lead and nickel-a pilot study. Food Addit. Contam. 20, 353-360.

Ernst E. (2000) Risks associated with complementary therapies. In: M.N.G. Dukes and J.K. Aronson, Editors, Meyler's Side Effects of Drugs (14th ed.). Elsevier, 1649-1681.

Ernst E. (2005) The efficacy of herbal medicine-an overview. Fundam. Clin. Pharmacol. 19, 405-409.

Ernst E, Coon J. (2001) Heavy metals in traditional Chinese medicines: a systematic review. Clin. Pharmacol. Ther. 70, 497-504.

Fong HH. (2002) Integration of herbal medicine into modern medical practices: issues and prospects. Integr. Cancer. Ther. 1, 287-293.

Georgiou GJ. (2005) The discovery of a unique natural heavy metal chelator. Explore. 14, 44-51.

Goulle JP, Mahieu L, Castermant J, Neveu N, Bonneau L, Laine G, Bouige D, Lacroix C. (2005) Metal and metalloid multi-elementary ICP-MS validation in whole blood, plasma, urine and hair: Reference values. Forensic Sci. Int. 153, 39-44.

Han S, Qiao X, Simpson S, Ameri P, Kemp FW, Bogden JD. (1996) Weight loss alters organ concentrations and contents of lead and some essential divalent metals in rats previously exposed to lead. J. Nutr. 126, 317-323. 
Hasegawa S, Nakayama K, Iwakiri K, An E, Gomi S, Dan K, Katsumata M, Minami M, Wakabayashi I. (1997) Herbal medicine-associated lead intoxication. Intern Med. 36, 56-58.

Kabelitz, L. (1998) Heavy metals in herbal drugs. Eur. J. Herb. Med., 4, 25-29.

Lim SS, Jung SH, Ji J, Shin KH, Keum SR. (2001) Synthesis of flavonoids and their effects on aldose reductase and sorbitol accumulation in streptozotocininduced diabetic rat tissues. Pharm. Pharmacol. 53, 653-668.

Lucas SR, Sexton M, Langenberg P. (1996) Relationship between blood lead and nutritional factors in preschool children: a cross-sectional study. Pediatrics 97, 74-78.

Miller GD, Massaro TF, Massaro EJ. (1990) Interactions between lead and essential elements: a review. Neurotoxicology 11, 99-120.

Mortada WI, Sobh MA, el-Defrawy MM, Farahat SE. (2002) Reference intervals of cadmium, lead, and mercury in blood, urine, hair, and nails among residents in Mansoura city, Nile delta. Egypt. Environ. Res. 90, 104-110.

Park YC, Lee SD, Park HM, Kim JB. (2006) Urine and hair metal concentrations in subjects with long term intake of herbal medicine. J. Toxicol. Pub. Health 22, 47-54.

Pierre JL, Baret P, Serratrice G. (2003) Hydroxyquinolines as iron chelators. Curr. Med. Chem. 10, 1077-1084.

Rabinowitz MB, Kopple JD, Wetherill GW. (1980) Effect of food intake and fasting on gastrointestinal lead absorption in humans. Am. J. Clin. Nutr. 33, 1784-1788.

Stata 7. (2001) Reference Manual Extract. Stata Press. US EPA. (1981) Interim methods for sampling and analysis of priority pollutants in sediments and fish tissue. US Environmental Protection Agency, Cincinnati, OH EPA 600/4-81-055.

US EPA. (2007) - The Framework for Metals Risk Assessment, March 8.

WHO. (1996) Trace elements in Human Nutrition and Health. World Health Organization, Genova. 258-259. 